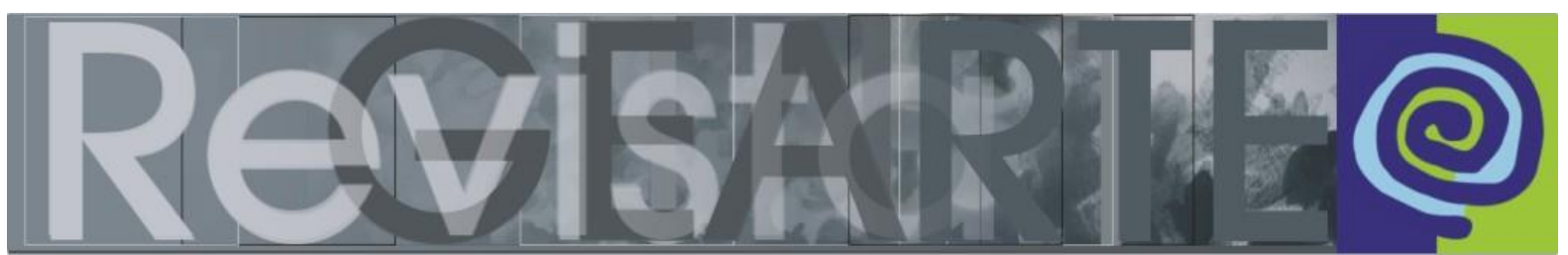

ISSN 2357-9854 | e-ISSN 2596-3198 (online)

\title{
Texturas da prática: narrativas de uma pedagoga sobre arte na formação docente
}

\author{
Luciana Esmeralda Ostetto (iD \\ (Universidade Federal Fluminense — UFF, Niterói/RJ, Brasil)
}

\begin{abstract}
RESUMO - Texturas da prática: narrativas de uma pedagoga sobre arte na formação docente - Como um mapa de saberes-fazeres desenhado com as marcas da memória de uma pedagoga, o artigo fala sobre experiências fertilizadas no encontro da educação com a arte, pelos territórios da docência e da pesquisa. A matéria advinda da rememoração de tempos, espaços, repertórios e práticas que constituem a história de formação e atuação profissional da autora dá a ver concepções e princípios sobre a presença da arte nos cursos de formação de professores, particularmente no curso de Pedagogia. Uma direção assumida no mapa traçado: a necessidade de desenhos curriculares que respeitem e acolham o professor em sua inteireza, que ofereçam espaço para a criação e a narrativa de si.
\end{abstract}

\section{PALAVRAS-CHAVE}

Educação e arte. Formação estética docente. Narrativas autobiográficas. Formação de professores. Curso de Pedagogia.

\begin{abstract}
Textures of practice: narratives of a pedagogue about art in teacher education - As a map of know-how drawn with the marks of a pedagogue's memory, the article talks about experiences fertilized in the encounter between education and art, through the territories of teaching and research. The material arising from the recollection of times, spaces, repertoires and practices that constitute the history of the author's training and professional performance reveals conceptions and principles about the presence of art in teacher training courses, particularly in the Pedagogy Course. A direction assumed in the map drawn: the need for curriculum designs that respect and welcome the teacher in their entirety, that offer space for the creation and self-narrative.
\end{abstract}

\section{KEYWORDS}

Education and art. Aesthetic teacher training. Autobiographical narratives. Teacher training. Pedagogy Course.

RESUMEN - Texturas de la práctica: narrativas de una pedagoga sobre arte en la formación docente - Como mapa de saberes-haceres diseñado con las marcas de la memoria de una pedagoga, el artículo habla sobre experiencias fertilizadas en el encuentro de la educación con el arte, por los territorios de la docencia y de la investigación. El material oriundo de la recolección de tiempos, espacios, repertorios y prácticas que constituyen la historia de formación y actuación profesional de la autora revela concepciones y principios sobre la presencia del arte en los cursos de formación de profesores, particularmente en el curso de Pedagogía. Una dirección asumida en el mapa trazado: la necesidad de diseños curriculares que respeten y acojan al docente en su totalidad, que ofrezcan espacios para la creación y la auto-narrativa.

PALABRAS CLAVE

Educación y arte. Formación estética docente. Narrativas autobiográficas. Formación de profesores. Curso de Pedagogía. 


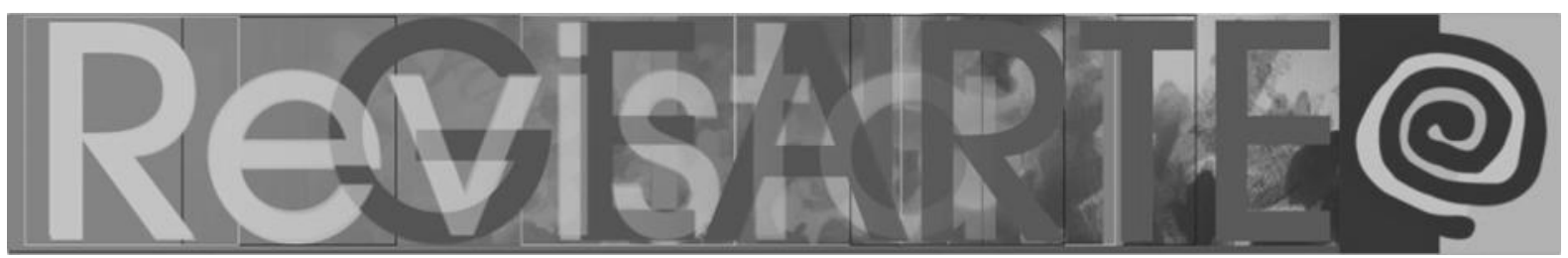

A Pedagogia, meu lócus de formação e de atuação, está na base do texto que anuncio. Desde esse lugar, pelo exercício de rememorar, revisito o passado atenta a lembranças e a imagens que falem de experiências fertilizadas no encontro da educação com a arte. Pelos caminhos da memória, busco mapear saberes-fazeres apropriados na jornada de ser professora e pesquisadora na área da formação docente para a Educação Infantil e que elege a arte como espaço de conhecimento privilegiado para o diálogo.

\section{Para um começo: princípios arrematados no tecido da experiência}

Para um começo, recolho do tecido da prática elementos que, feito pontos arrematados em um bordado ainda em processo, permitem visibilizar a composição que pouco a pouco vai ganhando forma. Apresento, pois, o desenho de princípios que, marcados pelos meus deslocamentos entre educação e arte, entre docência e pesquisa, hoje me orientam.

Desde que me envolvi com a formação de professores, fui testemunhando que a experiência estético-cultural docente, como conhecimento de mundo, incide significativamente nos processos de ensino-aprendizagem e, por isso, seria muito difícil, senão impossível, o professor encorajar a criança a viver uma aventura que ele mesmo não experimentou. Dessa compreensão, decorre a premissa: para acolher o outro criador, é necessário ativar o criador em si; para cultivar beleza, é preciso viver a beleza; para encantar, é preciso encantar-se (OSTETTO, 2010). Aproximar-se dos espaços de arte existentes ao redor, alimentar a disposição para a interação com as obras e as manifestações artístico-culturais são fatores de renovação dos sentidos. É imprescindível, portanto, convidar aqueles em formação a irem lá onde estão artes e artistas, de modo a provocar movimentos para, quem sabe, deslocar o olhar, fecundar a imaginação, ampliar repertórios imagéticos, estéticos, culturais, políticos. Além do que, criar tempos e espaços que favoreçam o reencontro do professor com sua dimensão lúdica, criadora, poeta, é essencial, haja vista que esse processo abre caminhos para o encontro com as crianças, para reconhecer suas linguagens e potencializar a poesia em seus saberes e fazeres. 


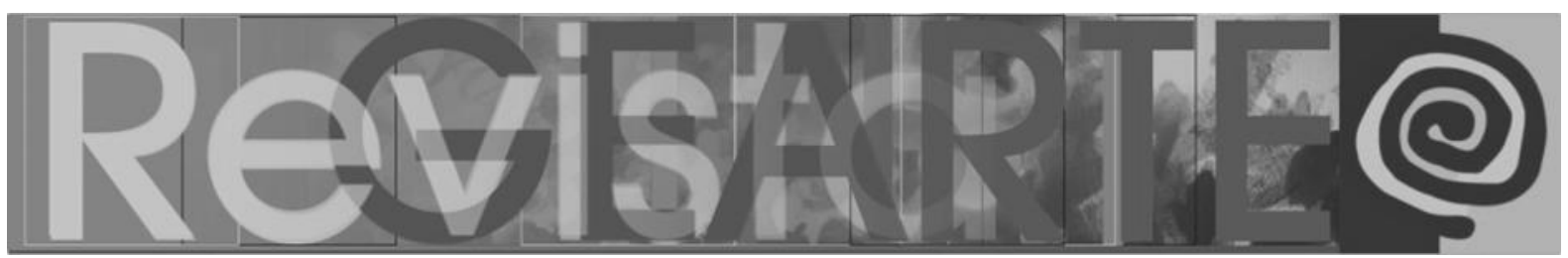

Ao conhecer o trabalho desenvolvido nas escolas de infância da cidade italiana de Reggio Emilia (entre leituras, nos anos de 1990 e viagens de estudo, nos anos de 2010), fui mobilizada pelas concepções de educação estética e linguagens expressivas nele implicadas. No projeto daquela rede de escolas, a centralidade do trabalho com as crianças está no campo ampliado das linguagens simbólicas, chamadas de linguagens expressivas e poéticas, que não se traduzem, na prática educativa, como ensino de arte. No âmbito de uma "educação holística" (VECCHI, 1999, p. 129), as linguagens poéticas são compreendidas como "[...] aquelas formas de expressão mais fortemente caracterizadas pelos aspectos expressivos e estéticos, como a música, o canto, a dança, a fotografia" (VECCHI, 2017 , p. 33). Profundamente presente no referido projeto, a arte, em suas diversas entradas - conceituais, práticas e simbólicas -, não se restringe a uma aula, ou a uma sessão no ateliê, mas atravessa, como fundamento, todo o cotidiano educativo, como oportunidades para a criança

[...] interrogar e indagar o mundo, construindo pontos e relações entre experiências e linguagens diversas, para tomar em estreita relação os processos cognitivos e aqueles expressivos, em contínuo diálogo com uma pedagogia que procura trabalhar sobre as conexões e não sobre as separações dos saberes (VECCHI, 2007, p. 139).

O diálogo com as teorias decorrentes da cuidadosa documentação e sistematização das experiências reggianas, na íntima relação que mantém entre arte e pedagogia, levaram-me a assumir, na formação docente, a perspectiva de uma formação estética, não necessariamente de ensino de arte. Aqui pontuo outra premissa, ao modo de um pensamento-guia: mais do que uma disciplina que afirme um campo de conhecimento, vislumbro a inserção da arte no curso de formação de professores (particularmente no curso de Pedagogia) como componente de um programa de formação cultural ampliado, articulado a propostas que levem à expansão de conhecimentos sensíveis e inteligíveis, ao refinamento dos sentidos e que potencializem oportunidades para a expressão poética do vivido. Além disso, como oportunidades para o acontecer de experiências que possam "acender coisas por dentro" (OSTETTO, 2006a, p. 42), que provocam possibilidades de sermos tocados, adultos e crianças, no cotidiano, pela beleza. 


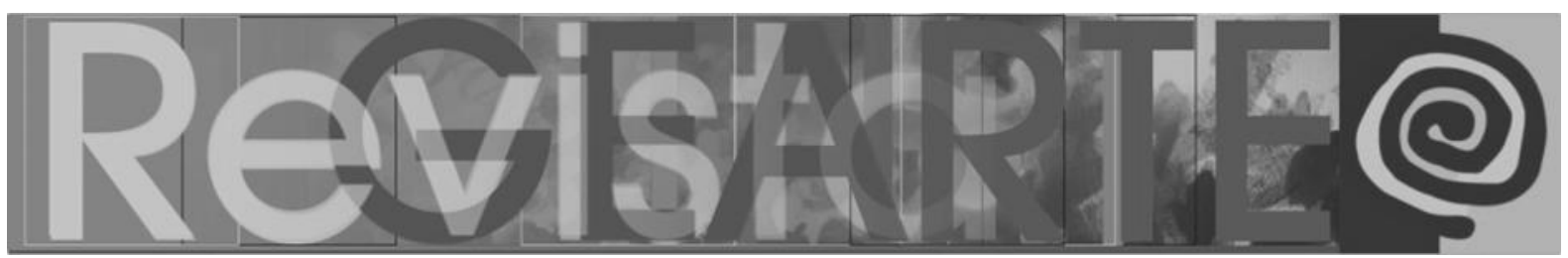

Formação estética, no contexto de uma proposta de formação docente, não se restringe ao trabalho com arte em diferentes linguagens, seus conceitos, suas práticas, suas especificidades, ou à apreciação da produção artística historicamente referenciada e disponível, nem, muito mesmo, caberia em um programa prescritivo, como a oferecer aos estudantes "o que Ihes falta", para educá-los no "bom gosto". Não. Como escrevi em trabalho recente, ao me referir à formação estética, quero falar,

[...] por um lado, do modo como nossos sentidos vão sendo afetados no percurso de nossas interações com a sociedade, a cultura, a natureza; por outro lado, das possibilidades de refinamento de tais sentidos, da ampliação do nosso repertório artístico-cultural, das oportunidades de aguçar a sensibilidade, de afetar e de ser afetado pelas coisas do mundo. Falar em formação estética docente, pois, conduz-nos a problematizar tempos, lugares e acontecimentos que possibilitam a experiência (do corpo) sensível, implicada em processos de percepção, de imaginação, de interpretação, no mundo e com o mundo, por meio dos quais a sensibilidade é alargada [...]. (OSTETTO, 2019, p. 10).

Uma necessidade, que vejo como mais um princípio para a jornada formativa, é a de pensarmos em desenhos curriculares que respeitem a pessoa na pessoa do professor, que acolham sua história e sua inteireza - corpo, alma, espírito -, que ofereçam espaço para a narrativa de si. Nessa direção, tensionando os referenciais para além dos campos da arte e da educação, pressupostos da psicologia analítica também compõem a fundamentação que venho assumindo nas propostas de formação docente. Com Carl Gustav Jung (1875-1961) e James Hillman (1926-2011), clarifico e fortaleço a ideia de que a formação estética se dá em deslocamentos, abrindo veredas para cultivar o ser da poesia e, de tal modo, as propostas precisam falar ao coração, centro da percepção estética e da imaginação, segundo a filosofia antiga, retomada por Hillman (2010). Note-se que, na perspectiva junguiana:

A realidade viva não é dada exclusivamente pelo produto do comportamento real e objetivo das coisas, nem pela fórmula ideal, mas pela combinação de ambos no processo psicológico vivo, pelo esse in anima. Somente através da atividade vital e específica da psique alcança a impressão sensível aquela intensidade, e a ideia, aquela força eficaz que são os dois componentes indispensáveis da realidade viva. (JUNG, 1991, p. 63). 


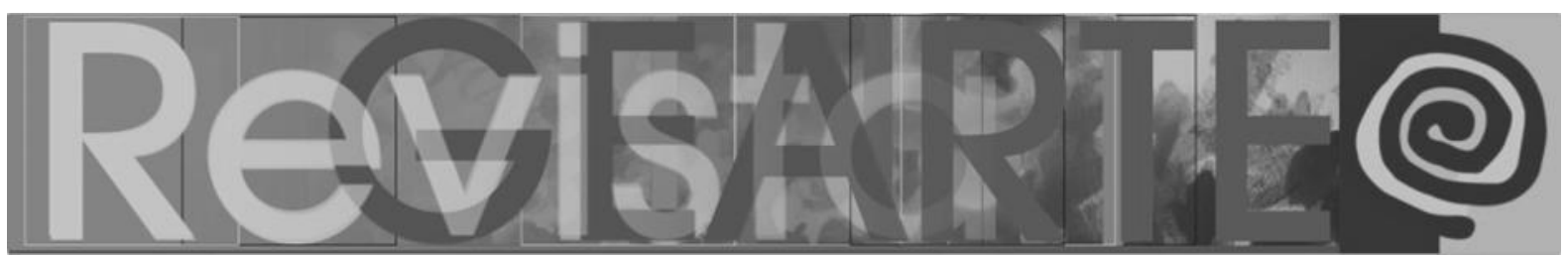

Esse in anima - estar na alma - é imaginar, esgarçar os limites impostos pela razão, simbolizar. Para a psicologia junguiana, simbolizar é atravessar fronteiras, fazer ligações, unir fragmentos, descobrir sentidos além do conhecido. Entregando-se a um curioso escutar o desconhecido para acolher o que nos chega, revitalizam-se os processos de criação. Articular arte, cultura e natureza em tempos curriculares que sejam mais cordiais e acolhedores, mais receptivos e menos interventores e/ou prescritivos, anuncia-se, pois, como possibilidade de fazer alma, no "[...] sentido primitivo e substancial de alma como poder de vida" (HILLMAN, 1984, p. 183 apud OSTETTO, 2019, p. 18).

$\mathrm{Na}$ esteira dos enunciados e referentes precedentes, nossas pesquisas no Círculo de estudo e pesquisa Formação de professores, Infância e Arte (FIAR) ${ }^{1}$, vêm sendo tecidas com palavras-chave tais como: arte e infância, formação de professores, Educação Infantil, educação em museus, formação cultural de professores, formação estética docente, narrativas autobiográficas, memorial de formação estética. Nossos estudos, de base teórico-metodológica firmada no campo da pesquisa (auto)biográfica (NÓVOA; FINGER, 2010; JOSSO, 2004, entre outros), têm se concentrado na tarefa de enfrentar o debate conceitual que relaciona educação, arte e formação estética. Algumas das questões que impulsionam nossas pesquisas: Onde acontece a formação estética do professor? Como suas histórias de vida contribuíram para sua formação estética? Qual é a contribuição da arte para a formação dos professores de Educação Infantil? Como a arte é vivida com as crianças, na Educação Infantil? Que conceitos e princípios orientam práticas artístico-culturais na Educação Infantil?

Entretanto, é preciso dizer, foi a docência no curso de Pedagogia, iniciada nos anos de 1990, que deu partida ao meu movimento de ir em busca da arte, para compreender conceitos e práticas, que me acendeu o desejo de garantir espaços de/com/pela arte na formação docente. É por ela que vou seguindo, explicitando histórias que me conduziram aos princípios apresentados até aqui. 


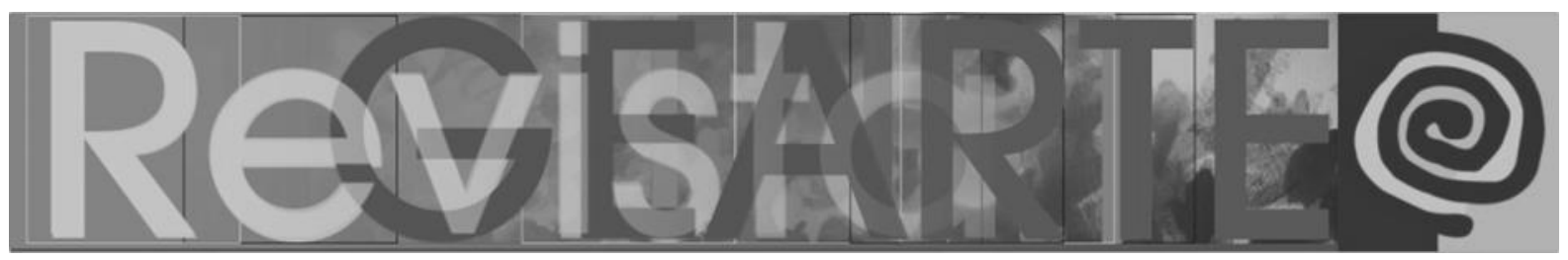

\section{Pedagogia, arte, aproximações, relações: passado}

Então professora do curso de Pedagogia da Universidade Federal de Santa Catarina (UFSC), nos anos de 1990, ministrava disciplinas específicas na área da Educação Infantil, entre teorias, metodologias e práticas pedagógicas relacionadas à atuação dos futuros professores de crianças de zero a seis anos. No espaço do componente curricular "Seminário especial de Educação Infantil", oferecido no último semestre do curso, podíamos trabalhar "temas que não foram contemplados ao longo do curso". Pois bem: arte não estava contemplada naquele currículo em que eu atuava, mas sua contribuição era evidente e a demanda, pelas próprias especificidades da docência na Educação Infantil, era crescente. Via seminários especiais, tínhamos, pois, uma brecha para trabalhar questões e conteúdos relacionados ao campo artístico-cultural. Pelas frestas, e de certa forma intuitivamente, eu propunha pensar, fazer, sentir e criar no diálogo e na experiência com múltiplas linguagens.

Nesse percurso, os encontros, os debates, os estudos cultivados com o Núcleo de Desenvolvimento Infantil², sobretudo com a arte-educadora que lá atuava, fecundavam experiências significativas para a relação arte, pedagogia, infância e formação. Juntas fomos tecendo uma metodologia desenhada por meio do que chamamos, à época, "oficinas de vivências", com o propósito de: ampliar o conhecimento sensível do futuro educador, possibilitando-lhe vivências lúdicas e criativas/criadoras; resgatar brincadeiras da infância que trazem aspectos da cultura popular, para subsidiar a prática pedagógica; abrir espaço para o encontro com as diferentes linguagens - dança, música, pintura, desenho, entre outras (OSTETTO; BROERING; FORTKAMP, 2009).

As oficinas potencializavam outras dimensões, como brincar, sentir, fantasiar, inventar formas, criar possibilidades, uma vez que não se pautavam em apresentação de modelos de brinquedos, de brincadeiras, de jogos ou de atividades do gênero, para serem copiados e reproduzidos com as crianças. As oficinas eram propostas como convite para as professoras em formação se 


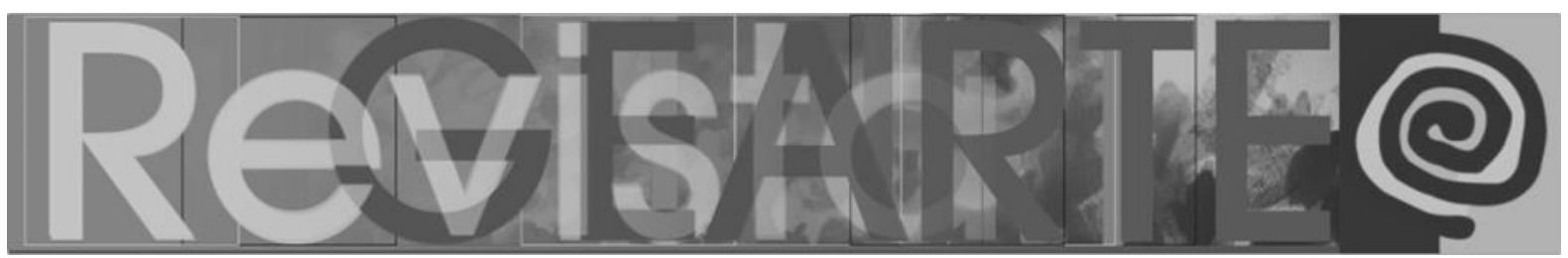

aventurarem por experiências de corpo inteiro, experimentando possibilidades de romperem barreiras instaladas em modos e jeitos do corpo, em atitudes e pensamentos culturalmente construídos e revelados, por exemplo, nas expressões frequentes: "Eu não sei desenhar", "Eu não sei fazer", "Não tenho o dom", "Não tenho jeito para isso"... Interações, diálogos e partilhas permitiam aprendizagens significativas, nas quais o "ser da poesia" (MOREIRA, 2002; OSTETTO, 2006a), presente-perdido no adulto-educador, ia sendo alimentado, resgatado das sombras a que fora relegado, pelas condições histórico-culturais da contemporaneidade, dentro e fora da escola e da universidade.

Essa experiência sinalizava a necessidade de uma formação que articulasse 0 que culturalmente fora fragmentado: pensar-fazer, razãosensibilidade, desejos-possibilidades, cabeça-coração-mãos. Confirmava que o resgate das expressões esquecidas pelos professores, a reconexão com as coisas simples, entre cantigas de roda e contato com materiais diversos, apoiava, encorajava e permitia aos educadores em formação o ensaio/exercício de uma prática pedagógica pautada na criatividade e na imaginação, pouco a pouco impulsionada pela reapropriação do seu particular processo de criação (OSTETTO, 2006b; OSTETTO; BROERING; FORTKAMP, 2009).

\section{Pequena história da pedagoga que assumiu a disciplina arte-educação}

Acompanhei a reformulação do curso de Pedagogia da UFSC, que trouxe consigo a inclusão da disciplina "Fundamentos e metodologia do ensino de arteeducação" no projeto curricular. O nome da disciplina não era nada novo, mas, como componente curricular, ampliava os fundamentos de base para a formação do professor e, assim, era portador de boas novas.

Quem ministraria a nova disciplina? Um professor com formação específica. Onde ele está? Aguardando um concurso. Tempos a esperar! Na espera, fui interpelada pela comissão de implementação da reforma curricular: - Tu poderias colaborar com a área, até que chegue um professor concursado? - Eu? - Sim, tu. 


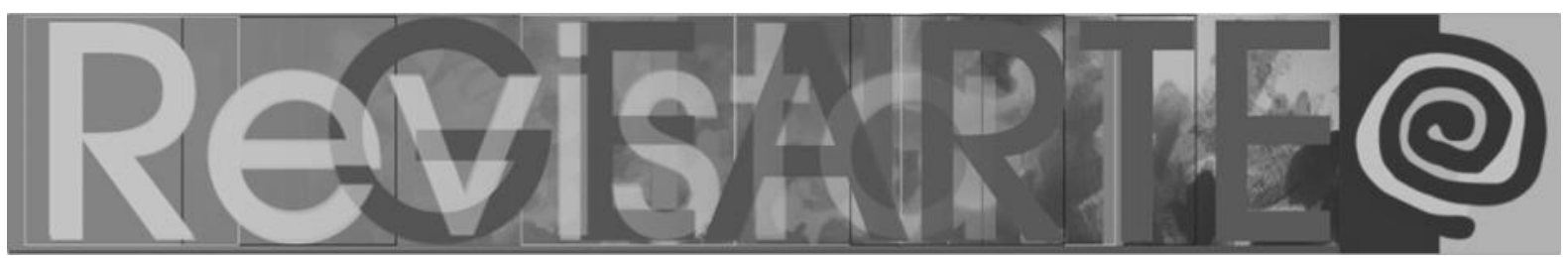

Assumirias a nova disciplina? - Mas... Eu sou pedagoga. - Ora, já não desenvolves um trabalho com arte, nos seminários especiais de Educação Infantil? -Verdade, mas... é diferente.

Enfrentando receios e desafios, aceitei. Aberta e com disposição a novas aprendizagens, apoiei-me na experiência acumulada com as oficinas desenvolvidas na área de Educação Infantil. Teci, então, um programa no qual a importância do contato com diferentes materialidades, técnicas de criação e de expressão, que pudessem provocar a educação do olhar, em experiências de corpo inteiro permanecia como diretriz. Era uma proposta de fazer, de experimentar, sustentada no objetivo de provocar a dimensão inventiva, claramente existente em cada um e, ao mesmo tempo, reprimida. Sair da sala de aula para ir lá onde a arte está também foi um princípio assumido à época, comprometido com a ampliação de repertórios artístico-culturais dos estudantes. Compreendendo a essencialidade de ver, contemplar, estar diante da obra, fruir, entre as atividades da disciplina estavam visitas a museus e galerias de arte, saídas para espetáculos de dança e de teatro.

Nesse tempo, pude contar com o apoio das professoras de arte do Colégio de Aplicação da $\mathrm{UFSC}^{3}$, que gentilmente vinham trabalhar na disciplina como convidadas e colaboradoras e trouxeram conhecimentos específicos, sobretudo das artes visuais, de forma a contribuir para fundamentar a jornada que estava sendo iniciada no curso de Pedagogia. Foi fundamental essa participação-apoio, tanto para o aprofundamento de conteúdos específicos que compartilhavam nas aulas com os estudantes, como para meu processo formativo estético-artísticocultural. Hoje, reconheço: com elas eu experimentei uma verdadeira formação continuada, traçada no encontro, no diálogo e na abertura para novos saberesfazeres advindos da arte. Reconheço, também, que tal componente curricular me possibilitou avançar no diálogo que vinha ensaiando com a arte como campo de conhecimento. 


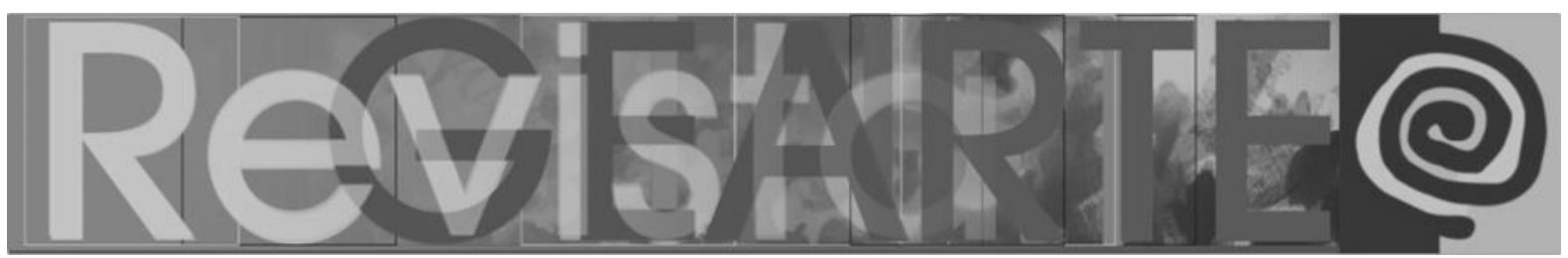

Com as primeiras turmas, realizei um "inventário artístico-cultural" e descobri que a quase totalidade dos estudantes não conhecia a Galeria de Arte da Universidade. Nessa galeria, localizada ao lado do Centro de Educação, a cada mês, uma nova exposição estava disponível. A proximidade da galeria, a oportunidade do acesso fácil às exposições com artistas e às obras diversas ao longo do semestre viabilizariam, sem maiores dificuldades, o encontro dos estudantes com um espaço que, abrigando um mundo desconhecido, poderia contribuir com o alargamento dos horizontes de cada um que se dispusesse à aventura de descobri-lo. Inseri no programa da disciplina a proposta de visitas mensais à galeria.

A proposta das visitas, formulada como um convite, sem pauta definida para o olhar, sem monitoramento, foi projetada para acontecer fora do horário curricular. A liberdade de ir e vir, de olhar, de interagir e de apreciar ao modo de cada um, articulava-se ao compromisso de, ao final do semestre, elaborar um ensaio com o intuito de problematizar seu olhar sobre as exposições acompanhadas na galeria de arte, de modo a refletir sobre o seu processo de significação da arte. As narrativas chegavam, contando sobre percepções e experiências do encontro com a obra, do deslocar-se à galeria, do estranhar, do apreciar, do refletir sobre limites e possibilidades. Compartilho trechos de duas delas:

\begin{abstract}
As obras eram interessantes, instigavam minha curiosidade, elas eram esquisitas. Acho que o diferente para nós é esquisito, porque se fossem obras de artes 'normais' (aqueles belos quadros de paisagens), talvez eu acharia tudo lindo e nem tentaria compreendê-los. Foi preciso olhar várias vezes para enxergar um pouquinho os sentimentos que a autora quis passar. Realmente temos pouca intimidade com obras de arte. Sei que preciso aprender muito e que o importante não é se eu entendo de arte, mas o meu interesse em ver e conhecer um pouco dela (Apreciação 1). (OSTETTO, 2011, p. 98).
\end{abstract}

Inicio a visita apressada, chateada, não muito disposta e desinteressada. Resumo: não vi nada. Mas decidi lançar um novo olhar para a exposição, buscando ver algo... [...]. Senti angústia e não tenho clareza se esta era devido às impressões que a exposição transmitia ou reflexo dos sentimentos que me cercavam no momento. Compreendo que a cada instante, a cada jeito de olhar as obras, dependendo do dia, das experiências vividas, a obra não me falará a mesma coisa. Acredito que isto se deva ao fato de as emoções colocadas pelo autor na obra estarem 


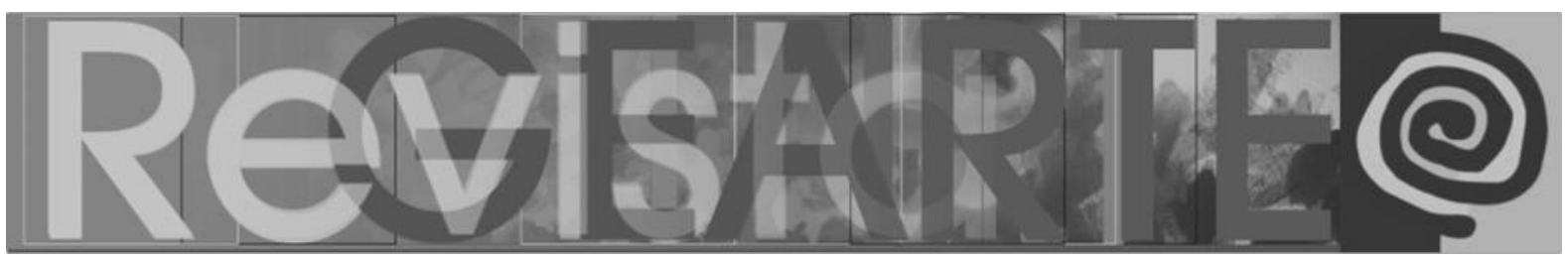

em direto confronto com as sensações de quem as observa. (Apreciação 5). (OSTETTO, 2011, p. 98).

Como não ser afetada pelas vozes pronunciadas? Essa experiência-convite - "Vá à galeria!" - reforçou em mim a compreensão da essencialidade da arte no curso de Pedagogia para além de um conteúdo disciplinar. Com tal proposta, pude confirmar que é fundamental convidar aqueles em formação a irem lá onde a arte está, que não basta falar sobre arte para os educadores. Talvez aqui esteja a gênese do meu pensamento sobre a arte inserida em um programa de formação cultural docente.

Quando deixei a disciplina, carregava comigo aprendizagens e questões despontadas na caminhada. Continuei nas especificidades, na escuta da prática, de creches e de pré-escolas, de educadores. Segui espreitando, e estreitando, cada vez mais as relações entre educação e arte, expandindo os limites fronteiriços, buscando no diálogo com a arte fecundas possibilidades para a formação docente.

\section{Fiando educação e arte nas veredas do curso de Pedagogia: presente}

$\mathrm{Na}$ continuidade de deslocamentos experimentados pelo desbravamento de outros territórios, no presente estou fiando histórias na formação de professores para a Educação Infantil, no curso de Pedagogia da Universidade Federal Fluminense (UFF). Ao percorrer outra estrutura curricular, mas que também não conta com uma disciplina específica da área de conhecimento arte, o diálogo com a arte vai sendo conquistado e projetado na ocupação de dois componentes curriculares: Atividades Culturais e Tópicos especiais em Educação Infantil.

Tal como descrito no Projeto Pedagógico de Curso, o componente curricular Atividades Culturais cumpre a função curricular de construir articulações da dimensão estética (parte integrante da formação do pedagogo, segundo estabelecido no artigo $5^{\circ}$ - inciso VI das Diretrizes Curriculares Nacionais para o curso de Pedagogia - Resolução № 1, de 15 de maio de 2006 (BRASIL, 2006), no 


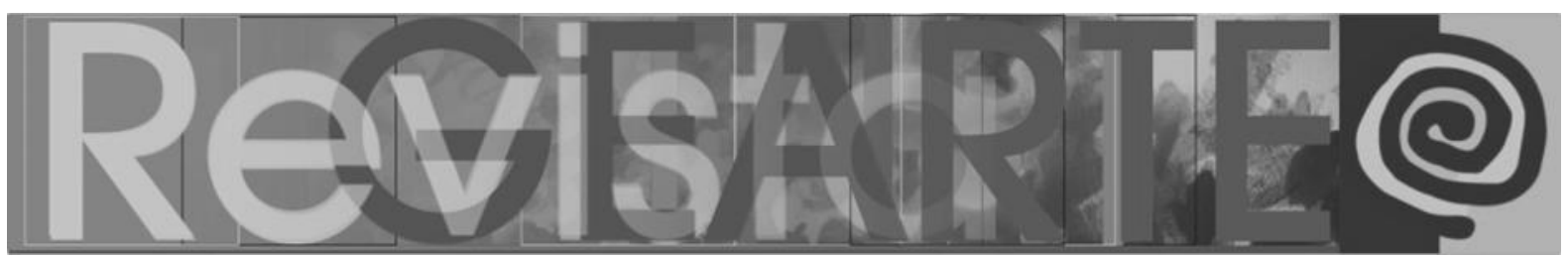

que diz respeito às aptidões do egresso do curso para ensinar Artes de forma interdisciplinar, na Educação Infantil e no Ensino Fundamental com as demais dimensões do perfil profissional (UFF, 2018). De caráter obrigatório, o referido componente tem por objetivo

[...] contribuir para o aprimoramento da formação geral e profissional dos estudantes e, fugindo do formalismo das disciplinas de nomenclaturas e conteúdos específicos, constituem-se como espaços de experienciação e aprendizagem de temas culturais - os mais diversos - que possam atualizar e ampliar a visão do pedagogo sobre o mundo, desenvolvendo sua sensibilidade estética, tanto na fruição como na expressão. (UFF, 2018, p. 37).

A cada semestre são oferecidas temáticas diversificadas, à escolha do estudante. Tenho trabalhado Atividades Culturais com a temática "Danças circulares: cultura, arte, educação". A proposta advém da minha pesquisa de Doutorado (OSTETTO, 2006b) e da experiência desenvolvida na disciplina optativa "Danças circulares sagradas e formação de professores", que criei e ministrei quando professora na UFSC. Para além de simples aulas de dança, a proposta tinha como foco a experiência do adulto-educador. Não havia a pretensão de ensinar "sobre" dança, escolas, princípios, conceitos e tal; tampouco pretendia apresentar danças de roda, ou treinar coreografias, para que depois fossem dançadas com/para as crianças na escola. O central era dançar na roda, ao sabor de diferentes culturas, traduzidas em ritmos, passos, compassos, movimentos, simbologias, e em grupo. Na base de tal dinâmica, uma premissa já anunciada: para fazer com a criança o adulto precisa fazer para si, pois não se pode encorajar o outro a viver uma aventura que nós mesmos não vivemos (MOREIRA, 2002).

$\mathrm{Na}$ dança circular, de mãos dadas, o grupo vivencia ritmos, gestos e simbologia de diferentes culturas, músicas e coreografias tradicionais e contemporâneas - são danças da Grécia, Albânia, Romênia, lugoslávia, Bulgária, Hungria, Macedônia, Israel, Escócia, Irlanda, Rússia, Letônia, Estônia, Lituânia, Índia, Brasil, povos celtas e da América do Sul, entre outras. As danças de pares são bastante comuns, mas a característica principal é a formação em círculo, que pode abrir-se ou fechar-se, desenhando linhas, espirais, meandros na sua 


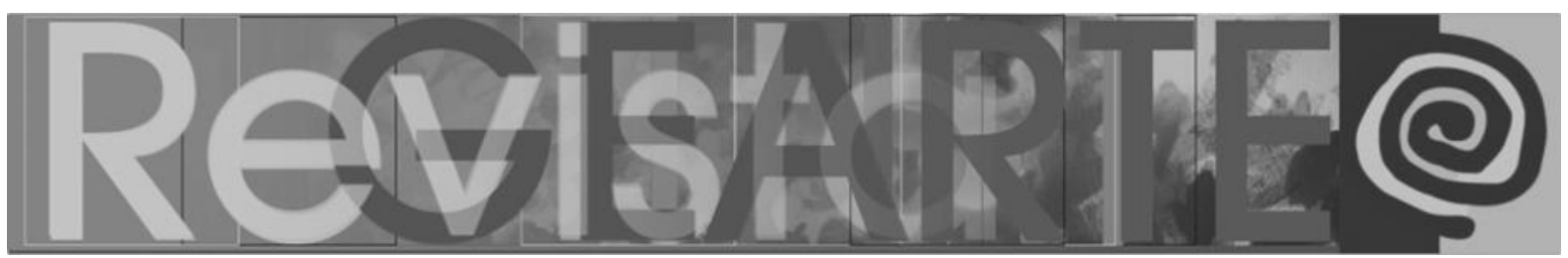

movimentação (OSTETTO, 2006b; OSTETTO, 2014). No processo, a cada dança, o coletivo é conduzido ao encontro do desconhecido presente nas diferentes culturas, é deslocado do lugar para suspeitar outros lugares - em si e no mundo. No contato com símbolos e rituais de diferentes culturas, faz-se uma travessia pelo inexplicável campo do mistério e, pelo exercício de imaginação ativa (JUNG, 1991), franqueando acesso ao território da criação.

A experiência da pesquisa e da disciplina inserida naquele currículo da UFSC (em 2006) deu-me as bases para a proposição de Atividades Culturais Danças circulares: cultura, arte, educação, no currículo da UFF (desde 2013), com carga horária semestral de 60 horas. Tendo por objetivo possibilitar o encontro com diferentes culturas e tradições, com destaque para simbolismos presentes nas danças circulares dos povos e sua relação com a educação, o programa está organizado em quatro tópicos: 1) Danças circulares de diferentes povos e tradições: vivências; 2) Danças circulares sagradas: fundamentos históricos, artísticos e culturais; 3 ) Rodas cantadas, brincadeiras de roda: das memórias de infância a novas experiências; 4) A circularidade na dança e na educação: princípios para a prática pedagógica. Metodologicamente, é desenvolvida por meio de encontros para dançar: o foco está na experimentação, na vivência das danças em roda, em grupo. Alguns encontros são dedicados à apreciação de filmes em vídeo, trazendo a temática e a estética da dança na sociedade, em diferentes culturas. Momentos para a socialização de impressões, de sensações, de relações estabelecidas, de ideias provocadas, de imagens surgidas, de comentários sobre as vivências também são previstos.

Por sua vez, Tópicos especiais em Educação Infantil, disciplina optativa com carga horária semestral de 60 horas, sinaliza, em sua ementa, o "Estudo aprofundado de tópicos específicos de importância e interesse em Educação Infantil" (UFF, 2018), de modo que possibilita várias entradas para temas e perspectivas de trabalho. Considerando que não há no desenho curricular do curso de Pedagogia da UFF uma disciplina específica do campo de conhecimento Arte, 


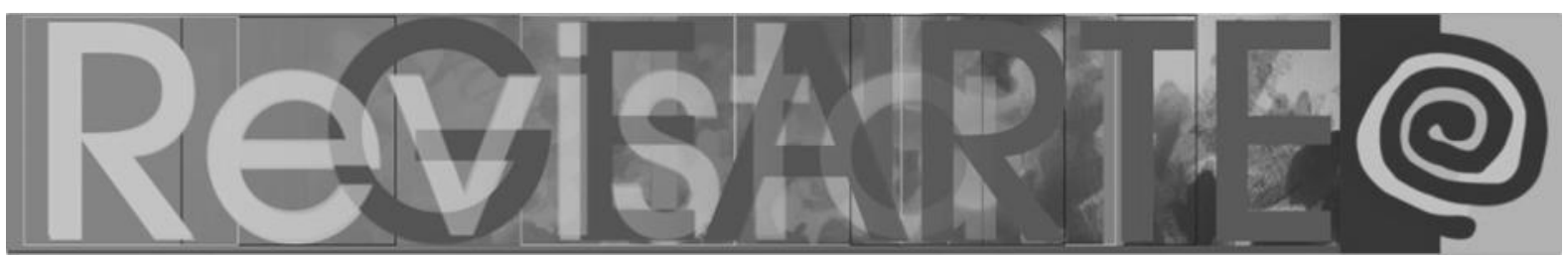

quando ministro Tópicos especiais em Educação Infantil, proponho a temática "Arte, infância e formação docente".

Nessa direção, para desenvolver o programa da disciplina, assumo como objetivo geral promover reflexões e experiências em torno de temas e de práticas relevantes à Educação Infantil, privilegiando a dimensão criadora do educador em formação, na articulação de saberes e de fazeres relacionados à arte e às linguagens expressivas da criança. Entre seus objetivos específicos, cito: aprofundar o conhecimento sobre aspectos específicos da prática pedagógica na Educação Infantil, de modo a analisar o espaço da arte no seu cotidiano; possibilitar reflexões sobre as linguagens expressivas, da criança e do adulto, por meio de estudos e de vivências; contribuir para a ampliação da sensibilidade do educador em formação, no diálogo com a memória e com as diferentes linguagens expressivas, promovendo o exercício de "desabituar" o olhar e todos os sentidos. O conteúdo programático está organizado em cinco tópicos, como temas-guias: 1) Experiência estética: das memórias às histórias de educadores; 2) Arte e infância: conceitos e experiências; 3) A decoração nos espaços educativos: para além de enfeite, educação visual; 4) Desenho: essa linguagem ainda incompreendida; 5) Educação e cultura, tradição e memória: danças e cantigas de roda. A metodologia inclui leitura e discussão de textos; exposição dialogada, mediada por imagens; debate a partir de vídeos; visita a museus e espaços culturais; oficinas de vivência e de criação; elaboração de narrativas autobiográficas.

Por ser uma disciplina teórico-prática, a avaliação é tomada como processo contínuo e considera principalmente a assiduidade e a participação efetiva nas atividades propostas. Como síntese do vivido, proponho também a elaboração de um "Diário poético de miudezas: memórias, histórias, ressonâncias", que pode assumir as mais variadas formas, nos mais diversos suportes, para abrigar coleções de imagens, de pensamentos, de sínteses, de fragmentos do vivido, recolhidos ao longo das aulas, no tempo compreendido entre o dentro e o fora da disciplina. É um espaço de autoria. Ao final do semestre, os diários são apresentados/compartilhados com todo o grupo.

OSTETTO, Luciana Esmeralda. Texturas da prática: narrativas de uma pedagoga sobre arte na formação docente. 494 Revista GEARTE, Porto Alegre, v. 8, n. 2, p. 482-508, maio/ago. 2021.

Disponível em: http://seer.ufrgs.br/gearte 


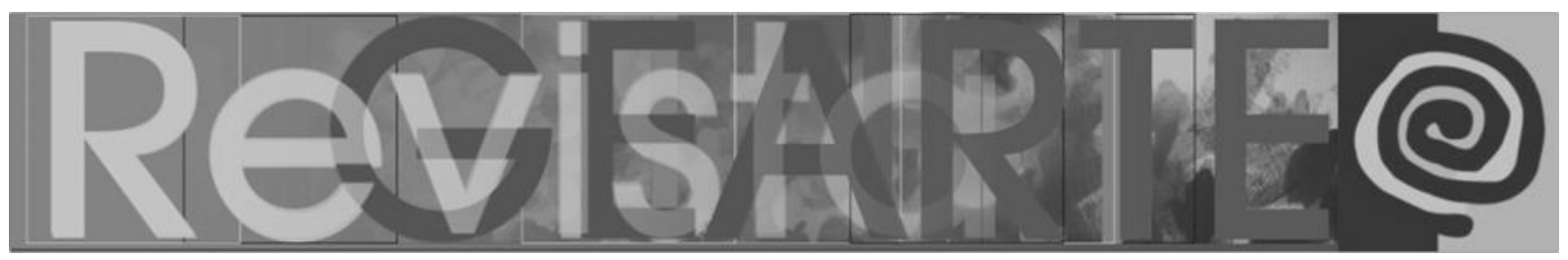

\section{Trilhas e rumos, cavando espaço para a arte que não há}

A organização e os conteúdos da disciplina vão sendo ajustados a cada semestre, na interação com cada grupo formado. Considerando os propósitos do presente texto, destacarei a seguir algumas trilhas percorridas no diálogo entre arte, infância e formação docente, no âmbito da disciplina Tópicos especiais em Educação Infantil, que desenvolvo no curso de Pedagogia da UFF.

\section{Como se...}

Para o primeiro dia de aula, tenho utilizado um dispositivo que hoje chamo de "Como se fora meu retrato: a imagem da arte fala de mim", que consiste em, diante de um postal com a reprodução de uma obra de arte, cada um falar de si "como se". Passa de mão em mão uma caixinha contendo inúmeros postais de obras de arte, de diferentes artistas. Cada participante apanha um, sem escolher, aleatoriamente. Ao olhar a imagem que the coube e convocar a imaginação, cada qual se apresenta como se ali, naquela imagem/obra, estivesse estampado o seu retrato. É um convite e uma provocação para olhares, imaginação, narrativas e ampliação de referências. Após as apresentações, conversamos sobre as obras retratadas nos postais que foram acessados, sobre os artistas, se os conhecem, o que sabem deles. No geral, a expressão é de desconhecimento da maioria dos artistas em exposição nos postais visibilizados, que são muito diversificados (fazem parte de minha coleção, marcas de andanças e encontros com a arte).

Para incrementar a discussão sobre essa singela experiência de dizer-se a partir de imagens da arte, trago a narrativa de uma professora de Educação infantil, em que ela fala sobre aspectos do percurso formativo de sua sensibilidade: "Meu encontro com Picasso... e comigo" (SILVA, 2006). Suas palavras contam da experiência escolar na infância, na qual o controle e a imposição de modelos eram a regra, do gosto e da curiosidade pelas cores e pelos artistas que conhecia folheando revistas em casa e de uma aventura-marco para sua formação estética e prática pedagógica com as crianças: viajar pela primeira vez de Florianópolis a São 


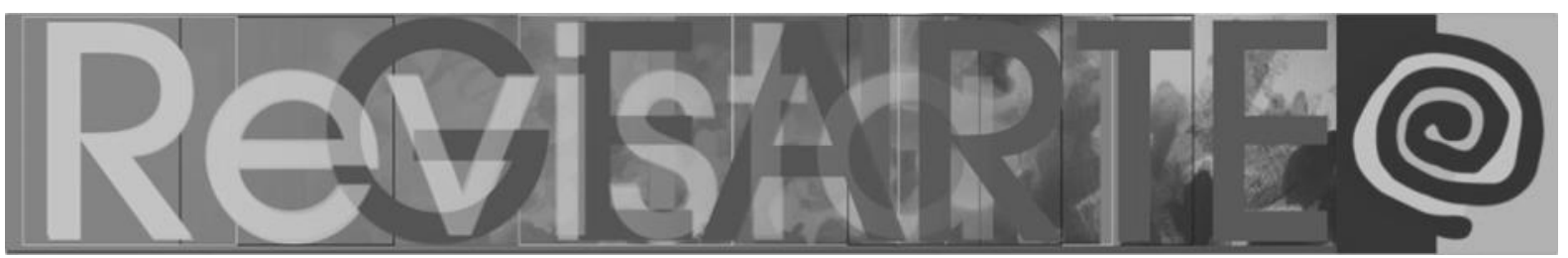

Paulo para ficar frente a frente com as obras de Pablo Picasso. Acompanhando venturas e desventuras da professora-narradora, o grupo de estudantes identificase muito facilmente com suas experiências na escola e as reduzidas oportunidades que eles próprios tiveram para o encontro com a arte. E, então, são eles a contarem sobre o que experimentaram na escola: entre o apontamento da interdição da experiência criativa e o cerceamento dos sentidos, trazem da memória que coloriam desenhos prontos, pintavam livremente em folhas A4 brancas, faziam os chamados "trabalhinhos" (com tinta guache, recorte-colagem, E.V.A., por exemplo), ensaiavam músicas, dancinhas e teatros para dias festivos.

Quanto ao repertório artístico-cultural, as experiências compartilhadas nas diferentes turmas revelam que, ao longo da vida, poucas oportunidades de encontro com a arte, objetos e expressões culturais fazem parte de suas histórias. Sem pretender dar aula de história da arte ou algo do gênero, percebi na proposta "Como se fora meu retrato: a imagem da arte fala de mim", descrita anteriormente, uma oportunidade para provocar pesquisa de imagens, de arte e de artistas. Sugiro, então, um encaminhamento para o próximo encontro: pesquisar outras obras dos referidos artistas, escolher duas dentre elas e enviar as imagens/obras selecionadas para meu e-mail, com um breve comentário sobre as razões das escolhas. Tal material é organizado em uma apresentação com a ferramenta PowerPoint, para ser projetada no encontro seguinte para o grupo todo. A apresentação dos artistas e de suas obras, acompanhadas de narrativas que dão a conhecer as razões da seleção, anima as reflexões sobre as formas de olhar, sobre a oportunidade, ou falta, de contato com a arte, sobre as concepções de feio/bonito, sobre o reconhecimento de suas histórias nas obras, entre outros pontos. Como apoio à reflexão sobre artes, artistas e olhares, lemos a crônica Vista cansada (RESENDE, 1992), o artigo O sensível olhar-pensante (MARTINS, 1996) e a introdução Sobre artes e artistas, de Gombrich (1999).

Apreciar filmes/vídeos sobre a temática como, por exemplo, o breve documentário Luigi Ghirri: pensar por imagens. Ícones, paisagens, arquiteturas (INSTITUTO MOREIRA SALLES, 2014) é uma boa continuidade para a conversa. 


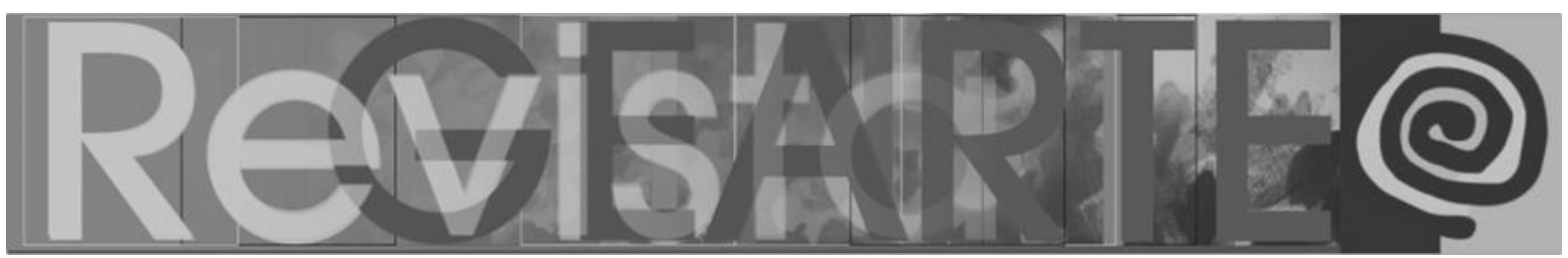

Nesse caso, o diálogo com a obra do fotógrafo italiano permite boas reflexões sobre o que olhamos, como olhamos, como capturamos o entorno, como consideramos ou excluímos os detalhes das paisagens que habitamos, o que, enfim, é digno de ser capturado e eternizado na memória, inclusive fotográfica.

A saída para explorar territórios não conhecidos no campus, ir lá onde normalmente não se vai, ou nunca se foi, capturar imagens de cantos e de paisagens descobertas, utilizando-se de um dispositivo que todos têm à mão nos dias de hoje, o celular, pode ser um desdobramento. Ou, na mesma direção, a proposta de fazer o percurso da universidade até suas casas com olhar mais aberto e observador, em busca de capturar o ínfimo, detalhes, paisagens que não haviam entrado no campo visual, ou foram secundarizadas por olhares ligeiros, superficiais, cansados, acostumados. As imagens registradas no formato digital são, então, compartilhadas com o grupo, de forma a atribuir a cada uma delas um título. Houve uma vez que a turma produziu descrições poéticas das suas imagens, além do título. Com uma das turmas, chegamos a realizar uma exposição, com as fotografias impressas e emolduradas. Tenho observado que esse simples exercício é prenhe de provocações e de convites à imaginação; é um significativo processo de cultivar linguagens e se abrir para possibilidades expressivas.

\section{Educação Infantil e arte: crianças, linguagens poéticas, narrativas sublimes}

Ao considerar que a disciplina é voltada à Educação Infantil, a discussão sobre arte e infância está no centro da proposta. Como porta de entrada para a identificação das principais questões que envolvem o tema, quase como um roteiro para a discussão, recorro à sistematização produzida no artigo Educação infantil e arte: sentidos e práticas possíveis (OSTETTO, 2008), do qual vamos puxando referências de outros interlocutores. Conforme as questões são identificadas e trazidas ao debate, faço indicações bibliográficas como apoio para a continuidade dos estudos. A depender do grupo e dos interesses evidenciados, escolho artigos de um ou outro autor para leitura compartilhada. Dentre os interlocutores 


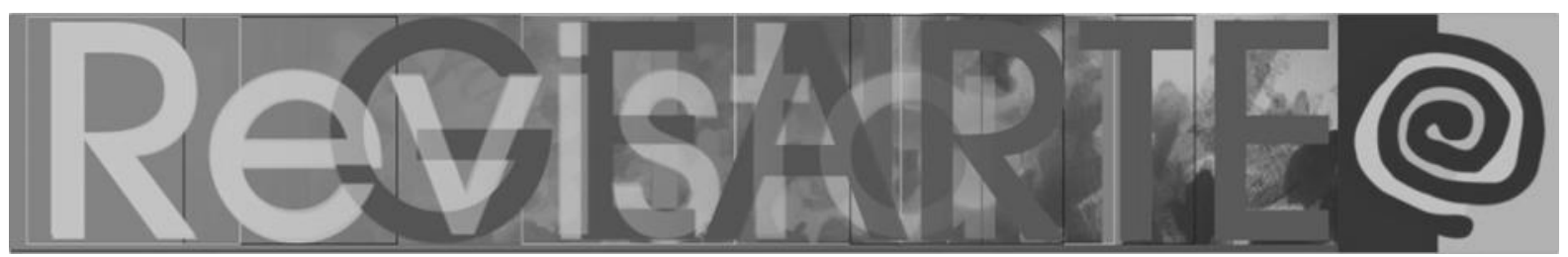

nomeados, duas figuras são presenças marcantes: uma artista contemporânea dinamarquesa e uma atelierista italiana.

Anna Marie Holm (1951-2015) desenvolvia oficinas de arte para crianças na Dinamarca e suas experiências (re)desenham concepções e práticas no que diz respeito à arte e à educação para/com a infância. Sua trajetória de proposições e de reflexões pode ser conhecida por meio das notas que escreveu em seus diários, posteriormente publicados no formato de livros, três dos quais traduzidos no Brasil (HOLM, 2005, 2007, 2015). Neles, a artista e educadora conta das produções, dos processos e dos sujeitos-produtores que participavam de suas oficinas e se envolviam nas singulares propostas que oferecia. Na leitura das publicações, identificamos um trabalho de/com arte profundamente enraizado na confiança que Anne Marie nutre pelas crianças, baseado no respeito aos modos próprios de ser, de conhecer e de expressar da infância, no reconhecimento e no acolhimento de suas múltiplas linguagens. Nos modos de propor e narrar as experiências, muitas vezes desenvolvidas em espaços e com materiais inusitados, a artista-educadora dá a conhecer "narrativas sublimes" (HOLM, 2007, p. 14) das crianças, capturadas com um olhar cuidadoso que põe em evidência o ser poético das infâncias.

Vea Vecchi, formada pela Academia de Belas Artes de Modena, Itália, trabalhou como atelierista ${ }^{4}$ na Escola de Infância Diana, de Reggio Emilia, desde o início dos anos 1970. Uma das principais colaboradoras de Loris Malaguzzi, precursor do projeto educativo desenvolvido nas escolas de infância da província de Reggio Emilia (HOYUELOS, 2006), contribuiu decisivamente para a construção de práticas e de teorias pedagógicas que reconhecem e acolhem "[...] a estética como uma das dimensões importantes na vida da nossa espécie e, portanto, também nas escolas e na aprendizagem" (VECCHI, 2017, p. 27). No livro Arte e criatividade em Reggio Emilia: explorando o papel e a potencialidade do ateliê na educação da primeira infância, Vecchi (2017), por meio de narrativas sensíveis e circunstanciadas, discorre sobre percursos, fundamentos e práticas relacionadas à arte e às linguagens expressivas naquele projeto. Ao evidenciar a importância 


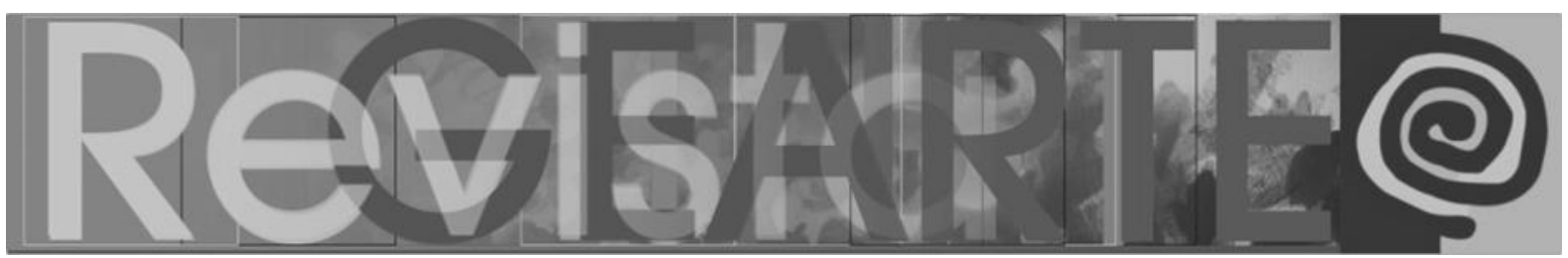

da experiência estética, que é mais ampla do que a experiência artística, ela pondera:

[...] dimensão estética talvez seja, antes de tudo, um processo de empatia que coloca em relação o sujeito com as coisas e as coisas entre si. [...]. E uma atitude de cuidado e de atenção para aquilo que se faz, é desejo de significado, é maravilhamento, curiosidade. É o contrário da indiferença e da negligência, do conformismo, da falta de participação e de emoção. (VECCHI, 2017, p. 28, grifo da autora).

Um elemento peculiar, e de todo potencialmente inovador nas abordagens sustentadas pela artista dinamarquesa e pela atelierista italiana, é que não se fecham na definição de metodologias ou enquadres conceituais da arte, mas assumem desafios com as crianças e se abrem às lógicas infantis. Teoria e prática artístico-estéticas estão imbricadas e se desenvolvem a partir de um foco: a criança. Para fundamentar a docência na Educação é uma posição basilar.

Nos dois últimos semestres em que ministrei essa disciplina, incluí um pequeno texto - Sobre Romero Britto, crianças e arte na educação infantil: vamos pensar sobre isso? - veiculado no blog https://papodepracinha.com.br e, posteriormente, publicado em livro (BORBA; DELORME, 2017). A leitura mostrouse oportuna para questionar a percepção, comum entre professores da Educação Infantil, de que tudo para criança deve ser alegre, colorido, gostosinho. Na esteira da reflexão suscitada pelas autoras, instala-se a crítica sobre referências propagadas pela indústria cultural, sobre gostos, sobre sequências didáticas empobrecidas e formatadas, sobre modos de fazer e sobre repertórios docentes. É deveras provocador.

Para ampliar a discussão sobre esse ponto (infância e arte) do programa da disciplina, também convido professoras de arte da Educação Básica para compartilharem experiências e reflexões sobre concepções e práticas. Oportunamente organizamos oficinas, transformando a sala de aula (por natureza imprópria) em um ateliê, ainda que improvisado, intencionalmente preparado. $\mathrm{O}$ foco está na experimentação e na composição com diferentes materialidades como, por exemplo, oficinas de aproximação à gravura, a partir de matrizes de 


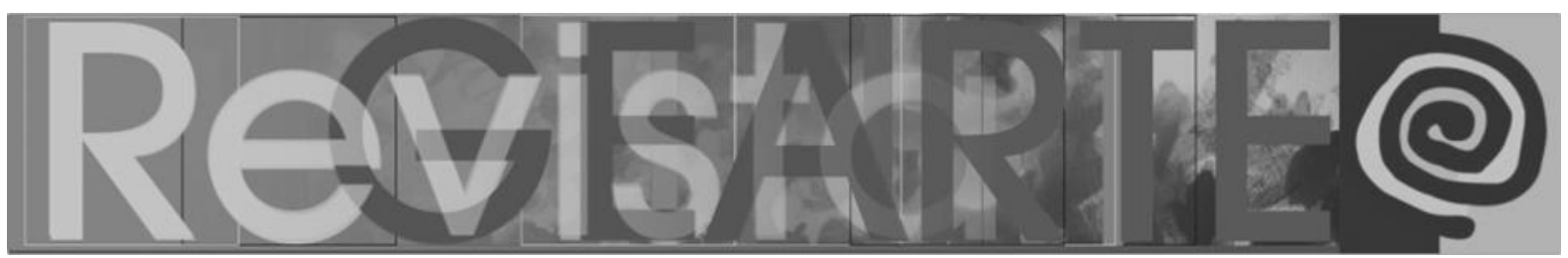

isopor, de desenho com carvão vegetal em suporte de papel Kraft e/ou papelão, de esculturas efêmeras, com materiais naturais recolhidos no campus.

Cantigas, brinquedos cantados e danças circulares também compõem oficinas que reiteram a importância do que tenho chamado de formação docente brincante (OSTETTO, 2018), no diálogo fecundo com os universos infantis e com as rememorações do adulto-estudante-professor em formação. Entre compartilhar cantigas revisitadas na memória do grupo, aprender novas cantigas e danças de roda tradicionais, problematizo a questão do gosto, a partir da leitura do artigo "Mas as crianças gostam!" ou sobre gostos e repertórios musicais (OSTETTO, 2004). Por vezes, apresento o documentário Tarja branca: a revolução que faltava (2014) e sempre trago a brincante Lydia Hortélio (2008), com o breve e precioso É preciso brincar para afirmar a vida.

\section{O espaço como elemento do currículo: instalações, relações}

Na Educação Infantil, o espaço é considerado um elemento do currículo, é constitutivo da aprendizagem e, portanto, precisa ser pensado, organizado, transformado em ambiente a partir de certos parâmetros de qualidade. Como indica Gandini (1999, p. 157): "Tudo o que cerca as pessoas na escola e o que usam - os objetos, os materiais, as estruturas - [são] elementos que condicionam e são condicionados pelas ações dos indivíduos que agem nela".

O espaço não é simplesmente uma circunscrição física, secundária, é um elemento que atua na constituição do pensamento: a maneira como o mobiliário é disposto e a presença de materialidades, de imagens, de cheiros, de sons educam as sensibilidades, potencializando ou subestimando os sentidos (RINALDI, 2013). A composição estética do espaço educacional precisa ser destacada, ao falarmos de arte na Educação Infantil, já que pode alargar ou restringir as oportunidades de exploração, de pesquisa e de experiências com as linguagens expressivas. De outro modo, é certo que os elementos que compõem um ambiente educacional, desde os objetos que o enfeitam até as imagens pregadas nas paredes, além de 


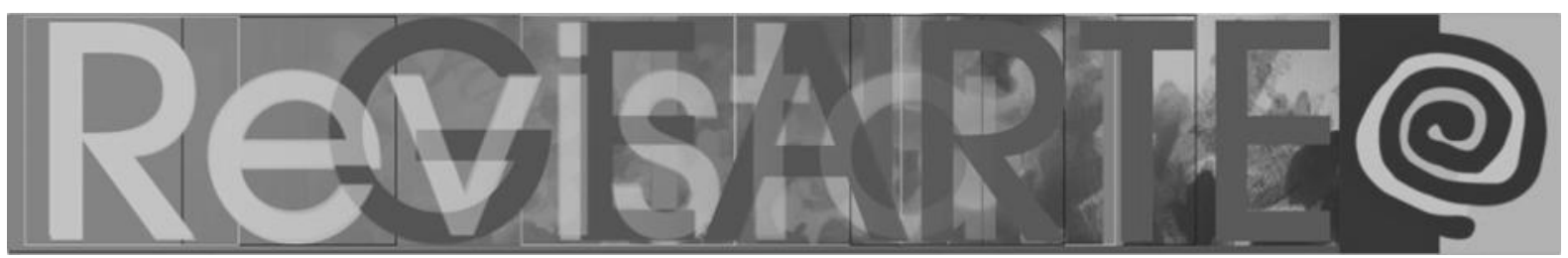

atuarem na formação do gosto das crianças, são textos visuais (CUNHA, 2005), impregnados de significados; constituem repertórios imagéticos-culturais que vão sendo apropriados e informam o pensamento.

Um conhecimento que vem da Pedagogia, o espaço como educador (GANDINI, 1999), é amplificado em seus significados no entrelaçamento dos conhecimentos advindos da Arte para configurar um princípio e um elemento imprescindível na formação de professores, que assim formulo: cuidar da estética dos espaços é parte do conteúdo de arte, no campo ampliado da formação estética. Nessa direção, visitar espaços de arte, observar projetos expográficos, projetar e experimentar intervenções em sala é um caminho fecundo. Trazer do campo artístico o conceito de instalação, suas qualidades e suas implicações espaciais é também um caminho fértil para desenvolver a reflexão proposta. Nesse ponto do percurso, focalizo leituras de base (CEPPI; ZINI, 2013; GANDINI et al., 2005) e proponho desafios para criarem intervenções com diferentes materialidades no espaço da sala de aula (que, às vezes, se estendem por corredores próximos), que se configurem como instalações. Em grupo, os estudantes discutem, desenham o projeto e o colocam em prática. Quando temos oportunidade de visitar exposições, amplifica-se, de modo extraordinário, a compreensão sobre formas de ocupação do espaço, sobre possibilidades e limitações determinadas pela organização espacial.

\section{Desenho perdido, desenho incompreendido}

Os desenhos para colorir ou copiar ainda compõem a lista privilegiada de "atividades de arte" propostas na Educação Infantil. Quando há "desenho livre", são comuns as intervenções do professor sobre a produção da criança, seja escrevendo/nomeando com sua letra "o que" a criança desenhou, seja dando um "retoque", para ficar bem apresentável e mostrar às famílias, por meio de exposições ou de coleções guardadas na pasta (ou, uma novidade, nos portfólios). É espantoso! Tanto mais se considerarmos o crescente número de estudos e de pesquisas que sistematizam teorias sobre o desenho na infância. Seja ele 


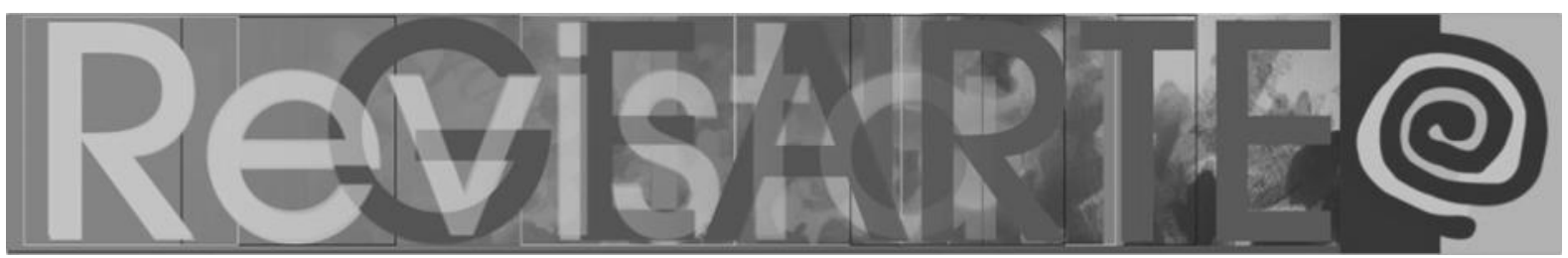

compreendido como natural, cultivado, aprendizagem cultural, desenvolvimento simbólico ou linguagem, o caso é que a prática corriqueira de ofertar desenhospadrão fotocopiados ou impressos para pintar (muitos com pretensão de ensinar a desenhar, ensinar limites gráficos, ensinar a reconhecer formas), permanece uma realidade na escola e na Educação Infantil.

No contato com professores, desde os tempos em que exercia a função de coordenadora pedagógica de creche e, depois, formando professores na universidade, dois aspectos foram evidenciados: o desconhecimento sobre as crianças e as teorias sobre o desenvolvimento da expressão gráfica e o total distanciamento de seu próprio desenho - os professores esqueceram seus traços pelo caminho de tornarem-se adultos. Diante da constatação, há tempos tomei por tarefa conjugar esses dois aspectos: compartilhar teorias sobre o desenho infantil e oportunizar vivências que pudessem franquear o reencontro com o desenho perdido. Considero que a discussão sobre o grafismo infantil é de fundamental importância para os professores de toda a Educação Básica. Se eu tivesse de escolher apenas um tópico para trabalhar com os estudantes, eu escolheria o desenho, abordando-o na articulação criança-adulto, memória-teoria-experiência.

No âmbito da disciplina "Tópicos especiais em Educação Infantil - arte, infância e formação docente", valho-me de um livro que foi inspirador para mim como professora de Educação Infantil: O espaço do desenho: a educação do educador, de Ana Angélica Albano Moreira (cuja primeira edição é de 1984). Não está aí apenas uma teoria sobre o desenho na perspectiva piagetiana, mas um convite à reflexão sobre percursos, experiências, sentidos, sensibilidades, memórias, imaginação de crianças e de adultos. É sobre vida e autoria. Para mim, esta é a contribuição original e precisa da autora: além de apresentar uma perspectiva do desenho, da criança, da escola, pontua com primorosa assertividade a importância, para o educador, de (re)descobrir o prazer em criar e de recuperar as linguagens da infância, perdidas ou esquecidas, como o desenho; de (re)aprender a espantar-se diante da novidade do mundo. Dessa forma, enuncia um conteúdo decisivo e imprescindível para ser contemplado na formação docente.

OSTETTO, Luciana Esmeralda. Texturas da prática: narrativas de uma pedagoga sobre arte na formação docente. Revista GEARTE, Porto Alegre, v. 8, n. 2, p. 482-508, maio/ago. 2021.

Disponível em: http://seer.ufrgs.br/gearte 


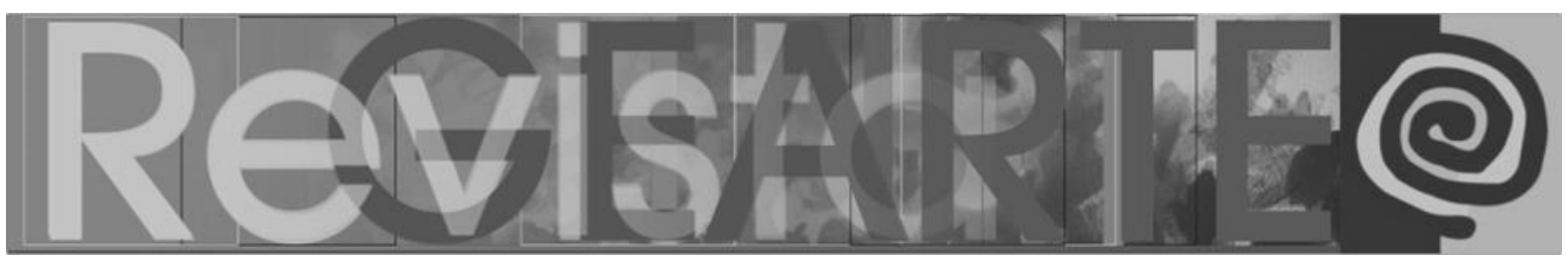

Ao reforçar que há muitas perspectivas de abordagem sobre o desenho na infância, também nomeio outros autores, caso queiram pesquisar e estudar. Contudo, sempre trabalho com o livro de Ana Angélica Albano Moreira (2002), do qual todo o grupo faz a leitura, destaca aspectos conceituais, articulando-os às experiências autobiográficas com o seu próprio desenho/desenhar ao longo da vida. Tenho para mim que:

\begin{abstract}
Para compreender e, principalmente, respeitar o desenho infantil, não basta apenas saber sobre as teorias do desenho, as fases de seu desenvolvimento ou significações psicológicas sobre o grafismo infantil; o educador precisa saber da sua própria produção, da sua expressão, da sua linguagem. Onde está o seu desenho? Ainda o leva consigo ou foi deixado no meio do caminho, entre a casa e a escola, entre a infância e a juventude? (OSTETTO, 2008, p. 10).
\end{abstract}

\title{
Sair para ver, ouvir, sentir: provocar desejos e espantos
}

Sair da sala de aula e levar o corpo inteiro para passear, avizinhar-se da produção artística, explorar espaços culturais já foram enunciados como um princípio, relacionado à ampliação de repertórios artístico-culturais dos estudantes. Na medida de movimentos e deslocamentos possíveis, no âmbito da disciplina, há o convite para ir ao encontro da obra, conhecer, contemplar, fruir. Visitas a museus e a galerias de arte têm sido garantidas pelo menos uma vez ao longo do semestre, a depender da disposição do grupo e do calendário acadêmico. Galeria de Arte da UFF, Espaço Cultural dos Correios/Niterói, Museu Janete Costa de Arte Popular/Niterói, Museu de Arte Contemporânea (MAC) de Niterói, Centro Cultural Banco do Brasil (CCBB) do Rio de Janeiro fazem parte de nossos roteiros.

Saídas para espetáculos de dança, de teatro e de concertos, são desejáveis, porém difíceis de organizar, devido à estrutura e aos tempos curriculares e pessoais dos estudantes. De toda forma, divulgo a agenda cultural próxima com o convite e a provocação para que conheçam e experimentem, independentemente de ação curricular. Certa vez tivemos a oportunidade de participar de uma sessão do programa Cine-escola, no Cinema da UFF. A proposta veio de uma das alunas, que viu a divulgação do filme em cartaz: Com amor, Van 


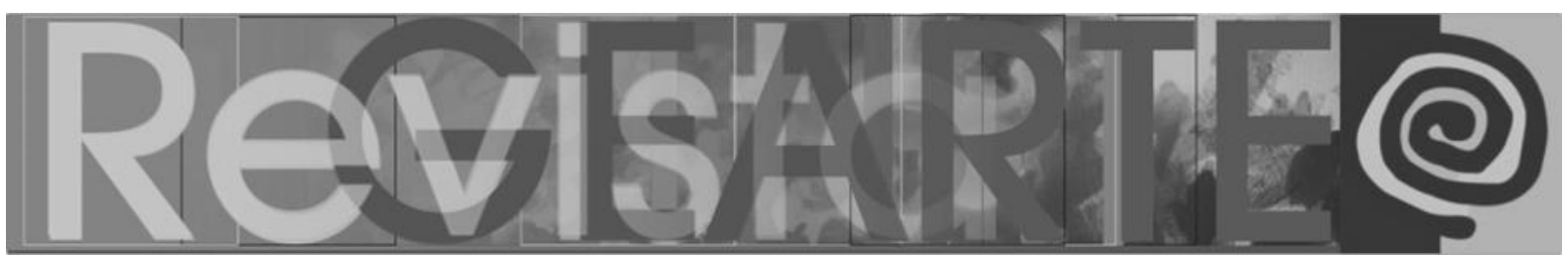

Gogh (2017). O horário era compatível, a entrada franca, organizamo-nos e lá fomos nós em aventura coletiva impulsionada pela mobilização dos estudantes. Depois da sessão, uma pergunta corriqueira: quem já conhecia o Cine Arte UFF? Três ou quatro, de um grupo de 22 estudantes. Na simplicidade da proposta, foi mesmo uma singela aventura, carregada de significado para aquele grupo que estava visivelmente mobilizado e conectado com a cabeça e com o coração.

Importante assinalar que as propostas de saídas não estão subordinadas a qualquer conteúdo ou proposta em desenvolvimento na disciplina. Vez ou outra, sincronicamente, uma ou outra exposição em cartaz dialoga especialmente com alguma questão discutida em sala. O que impulsiona a saída é o desejo de ir lá onde a arte está, é o chamado para o encontro - disposição a explorar e acolher outros espaços, outras experiências.

\section{Para um final: que sejamos todos artistas!}

$\mathrm{Na}$ jornada narrativo-reflexiva traçada, reencontrei-me com Elliot Eisner (1933-2014) e sua proposição de examinar "[...] o que uma concepção de prática enraizada nas artes pode contribuir para o melhoramento dos meios e dos fins da educação" (EISNER, 2008, p. 2). Suas ideias, claras e certeiramente articuladas no artigo $\mathrm{O}$ que pode a educação aprender das artes sobre a prática da educação?, partem da crítica às propostas educacionais contemporâneas, calcadas em raízes cognitivistas, sustentadas pela uniformidade de expectativas, de objetivos, de conteúdos, de avaliação. Com os olhos na história, ele revisita fundamentos para uma outra educação, apresenta e discute formas de pensar advindas das artes para, então, delas destacar elementos que considera imprescindíveis para compor uma concepção de educação sustentada na importância da exploração, da surpresa, do acolhimento da diversidade, que dê mais valor ao tornar-se do que ao ser. Em suas palavras:

Sob o risco de propagação de dualismos, mas ao serviço da evidência, estou a falar de uma cultura de escolarização na qual está localizada maior importância na exploração do que na descoberta, é dado mais valor à surpresa que ao controlo, é dedicada mais atenção ao que é distintivo 


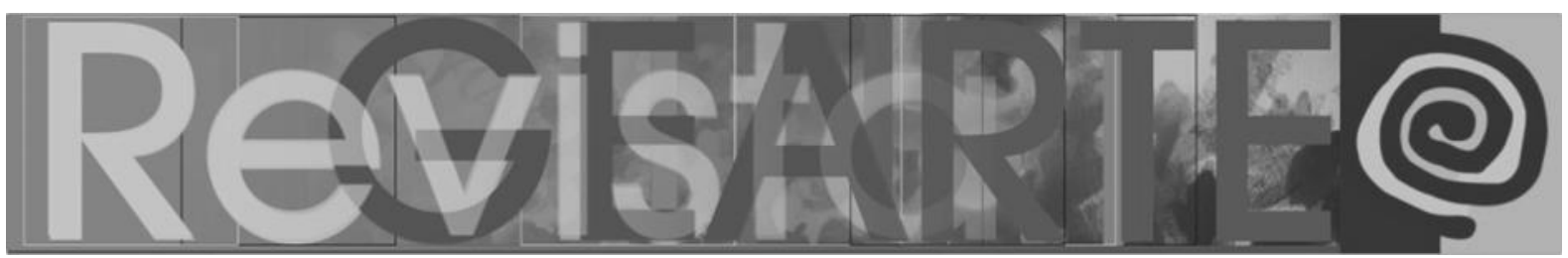

do que ao padronizado, é dado mais interesse ao que está mais relacionado com o metafórico do que com o literal. E uma cultura educacional que tem uma maior focalização no torna-se do que no ser, dá mais valor ao imaginativo do que ao factual, dá uma maior prioridade ao valorizar do que ao avaliar e, considera a qualidade da caminhada mais significante do que a velocidade a que se chega ao destino. (EISNER, 2008, p. 12).

Quando conheci Elliot Eisner, reconheci princípios que fizeram muito sentido para minha prática docente, atenta à necessidade da arte para a formação de professores. Agarrei-os. Não é minha intenção aprofundar a concepção apresentada, já que estou perto do ponto final. Quero apenas destacar um fragmento, no qual o arte-educador problematiza a necessidade de a educação trabalhar e oportunizar diferentes formas de pensar, dentre as quais aquelas enraizadas no artístico, oferecendo-nos contributos decisivos para a discussão sobre arte na formação humana e, por conseguinte, sobre arte e formação docente, arte e pedagogia.

Sem mais delongas, puxo o fio do arremate textual iluminando um enunciado: "O objetivo da educação deveria ser entendido como a preparação de artistas", defendido por Herbert Read (1893-1968) e sobre o qual pondera Eisner:

\begin{abstract}
Pelo termo artista nem ele [Herbert Read], nem eu, queremos dizer necessariamente pintores, dançarinos, poetas ou autores dramáticos. Nós queremos dizer indivíduos que desenvolveram as ideias, as sensações, as habilidades e a imaginação para criar um trabalho que está bem proporcionado, habilmente executado e imaginativo que é independente do domínio em que um indivíduo trabalha. [...]. As belas artes não têm o monopólio do artístico. (EISNER, 2008, p. 5).
\end{abstract}

Enfatizo que não sou professora de arte, mas quero ser esse tipo de artista. Sigamos, reaproximando o que historicamente fora apartado! Grata pela oportunidade de diálogo.

\title{
Notas
}

1 Para mais informações do grupo, consultar http://fiar.sites.uff.br/.

2 O Núcleo de Desenvolvimento Infantil (NDI), Instituição de Educação Infantil ligada ao Centro de Ciências da Educação da Universidade Federal de Santa Catarina está localizado no interior do Campus Universitário da UFSC, em Florianópolis-SC. À época, foram fundamentais a 


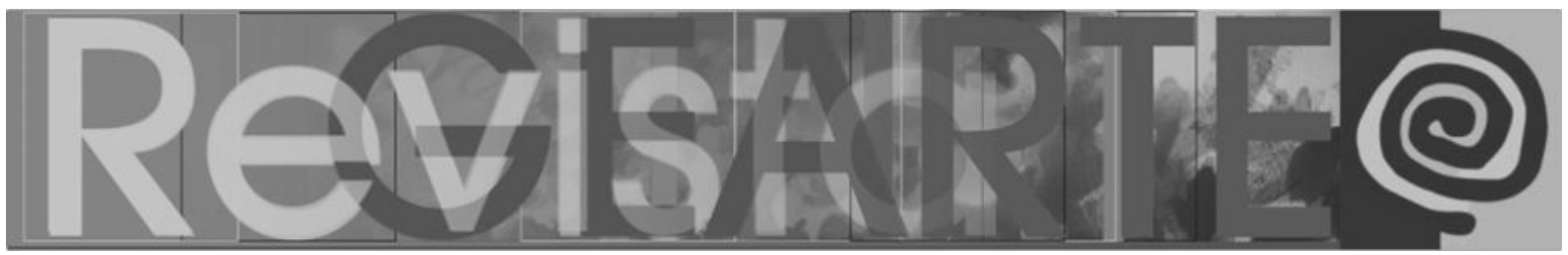

interlocução e o acolhimento da arte-educadora Vânia Broering, a quem agradeço, mais uma vez, pelo ensinar-aprender arte em diálogo.

3 Guardo comigo a lembrança da gentileza e da competência de Fabíola Cirimbelli Búrigo Costa e Neide Pelaez de Campos, professoras de arte do Colégio de Aplicação da UFSC, às quais serei sempre agradecida.

4 As escolas de infância de Reggio Emilia não trabalham com professores de arte, mas com atelieristas, os quais possuem formação artística, mas não necessariamente pedagógica, e assumem um papel diverso da docência em arte, trabalhando com crianças e adultos (VECCHI, 1999, 2017; GANDINI et al., 2012).

\section{Referências}

BORBA, Angela; DELORME, Maria Inês de Carvalho. Sobre Romero Britto: crianças e arte na educação infantil. In: BORBA, Angela; DELORME, Maria Inês de Carvalho (Orgs.). Infância fora da asa. Rio de Janeiro: Grupo Multifoco, 2017, p. 192-195.

BRASIL. Resolução no 1, de 15 de maio de 2006. Institui Diretrizes Curriculares Nacionais para o Curso de Graduação em Pedagogia, licenciatura. Diário Oficial da União: seção 1, Brasília, DF, n. 92, p. 11-12, 16 maio 2006.

CEPPI, Giulio; ZINI, Michele (Orgs.). Crianças, espaços, relações: como projetar ambientes para a educação infantil. Porto Alegre: Penso, 2013, p.122-143.

COM AMOR, Van Gogh. Direção Dorota Kobiela e Hugh Welchman. [Reino Unido, Polônia]: Europa Filmes, 2017. 1 CD-ROM (95 min), son., color.

CUNHA, Susana Rangel Vieira da. Um pouco além das decorações das salas de aula. Reflexão e Ação, Santa Cruz do Sul, v. 13, n. 1, p. 133-149, jan./jun. 2005.

EISNER, Elliot W. O que pode a educação aprender das artes sobre a prática da educação? Currículo sem Fronteiras, v. 8, n. 2, p. 5-17, jul./dez. 2008.

GANDINI, Lella. Espaços educacionais e de envolvimento pessoal. In: EDWARDS, Carolyn; GANDINI, Lella; FORMAN, George (Orgs.). As cem linguagens da criança: a abordagem da Reggio Emilia na educação da primeira infância. Porto Alegre: Artes Médicas, 1999, p. 145-158.

GANDINI, Lella. et al. (Org.). O papel do ateliê na educação infantil: a inspiração de Reggio Emilia. Porto Alegre: Penso, 2012.

GOMBRICH, Ernst Hans. Introdução: sobre artes e artistas. In: GOMBRICH. Ernst Hans. A história da arte. Rio de Janeiro: LTC, 1999, p. 15-37.

HILLMAN, James. O pensamento do coração e a alma do mundo. Campinas: Verus, 2010.

HOLM, Anna Marie. Baby-art: os primeiros passos com a arte. São Paulo: Museu de Arte Moderna de São Paulo, 2007.

HOLM, Anna Marie. Eco-arte com crianças. São Paulo: Ateliê Carambola, 2015.

HOLM, Anna Marie. Fazer e pensar arte. São Paulo: Museu de Arte Moderna de São Paulo, 2005.

HORTÉLIO, Lydia. É preciso brincar para afirmar a vida. Almanaque de cultura popular - Revista de bordo da TAM, n. 114, p. 23-25, out. 2008.

HOYUELOS, Alfredo. La estética en el pensamiento y obra pedagógica de Loris Malaguzzi. Barcelona: Ediciones Octaedro; Rosa Sensat, 2006.

INSTITUTO MOREIRA SALLES. Luigi Ghirri: pensar por imagens. Ícones, paisagens, arquiteturas. São Paulo: Instituto Moreira Salles, 2014.

JOSSO, Marie-Christine. Experiências de vida e formação. São Paulo: Cortez, 2004.

OSTETTO, Luciana Esmeralda. Texturas da prática: narrativas de uma pedagoga sobre arte na formação docente.

Revista GEARTE, Porto Alegre, v. 8, n. 2, p. 482-508, maio/ago. 2021.

Disponível em: http://seer.ufrgs.br/gearte 


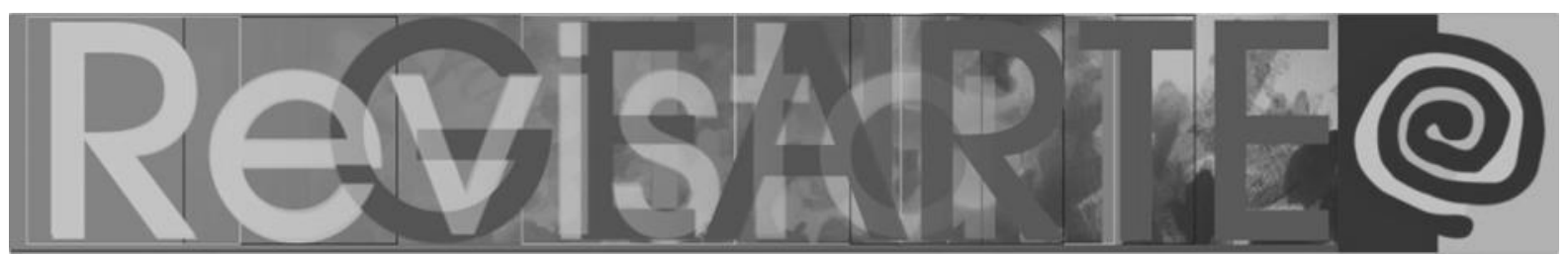

JUNG, Carl Gustav. O espírito na arte e na ciência. 3. ed. Petrópolis: Vozes, 1991.

MARTINS, Mirian Celeste. O sensível olhar-pensante. In: FREIRE, Madalena (Org.). Observação, registro, reflexão. São Paulo: Espaço Pedagógico, 1996, p. 20-37.

MOREIRA, Ana Angelica Albano. O espaço do desenho: a educação do educador. São Paulo: Loyola, 2002.

NÓVOA, António Sampaio da; FINGER, Matthias (Org.). O método (auto)biográfico e a formação. Natal: EDUFRN; São Paulo: Paulus, 2010.

OSTETTO, Luciana Esmeralda. "Mas as crianças gostam!" ou sobre gostos e repertórios musicais. In: OSTETTO, Luciana Esmeralda; LEITE, Maria Isabel (Orgs.). Arte, infância e formação de professores: autoria e transgressão. Campinas: Papirus, 2004, p. 41-60.

OSTETTO, Luciana Esmeralda. A arte no itinerário da formação de professores: acender coisas por dentro. Reflexão e Ação, Santa Cruz do Sul, v. 14, n. 1, p. 29-43, jan./jun. $2006 a$.

OSTETTO, Luciana Esmeralda. Arte, educação estética, formação cultural: experiências com estudantes do curso de Pedagogia. In: FERREIRA, Luciana Haddad (Org.). Arte de olhar: percursos em educação. Campinas: llion, 2011, p. 94-107.

OSTETTO, Luciana Esmeralda. Crianças, professores, educação infantil: por uma formação brincante. In: ARIOSI, Cinthia Magda Fernandes (Org.). Pelo direito de brincar: reflexões e experiências. Curitiba: CRV, 2018, p. 59-71.

OSTETTO, Luciana Esmeralda. Danças circulares na formação de professores: a inteireza de ser na roda. Florianópolis: Letras Contemporâneas, 2014.

OSTETTO, Luciana Esmeralda. Educação infantil e arte: sentidos e práticas possíveis. Florianópolis: UFSC - Centro de Ciências da Educação, 2008. Disponível em: http://www.acervod igital.unesp.br/bitstream/123456789/320/1/01d14t01.pdf. Acesso em: 10 abr. 2020.

OSTETTO, Luciana Esmeralda. Educadores na roda da dança: formação-transformação. 2006. 250 f. Tese (Doutorado em Educação) - Faculdade de Educação, Universidade Estadual de Campinas, Campinas, 2006b.

OSTETTO, Luciana Esmeralda. Esse in anima: formação docente em deslocamento. In: REUNIÃO NACIONAL DA ANPED, 39., 2019, Niterói. Anais... Niterói: UFF, 2019. Disponível em: http://anais.anped.org.br/sites/default/files/gt07_trabalho_encomendado_formatado_39_rn_2_luciana_esmeralda_ostetto.pdf. Acesso em: 10 abr. 2020.

OSTETTO, Luciana Esmeralda. Para encantar, é preciso encantar-se: danças circulares na formação de professores. Cadernos CEDES, Campinas, v. 30, n. 80, p. 40-55, jan./abr. 2010.

OSTETTO, Luciana Esmeralda; BROERING, Vânia Maria; FORTKAMP, Eloisa Helena Teixeira. A dimensão estética na formação do professor de educação infantil. In: CARVALHO, Diana Carvalho de et al. (Orgs.). Experiências pedagógicas com ensino e formação docente: desafios contemporâneos. Araraquara: Junqueira e Marins; Florianópolis: FAPEU, 2009, p. 169-180.

RESENDE, Otto Lara. Vista Cansada. Folha de São Paulo, São Paulo, 23 fev. 1992. Disponível em: https://cronicabrasileira.org.br/cronicas/7040/vista-cansada. Acesso em: 10 abr. 2020.

RINALDI, Carla. O ambiente da infância. In: CEPPI, Giulio; ZINI, Michele (Orgs.). Crianças, espaços, relações: como projetar ambientes para a educação infantil. Porto Alegre: Penso, 2013, p. $122-128$.

SILVA, Samantha Fernandes da. Meu encontro com Picasso... e comigo. In: LEITE, Maria Isabel; OSTETTO, Luciana Esmeralda (Orgs.). Museu, educação e cultura: encontros de crianças e professores com a arte. Campinas: Papirus, 2006, p.157-161.

TARJA BRANCA: a revolução que faltava. Produção: Maria Farinha Filmes. São Paulo: Alana, Maria Farinha Filmes, Quintal de Trocas, 2014. (79 min), son., color. Disponível em: 


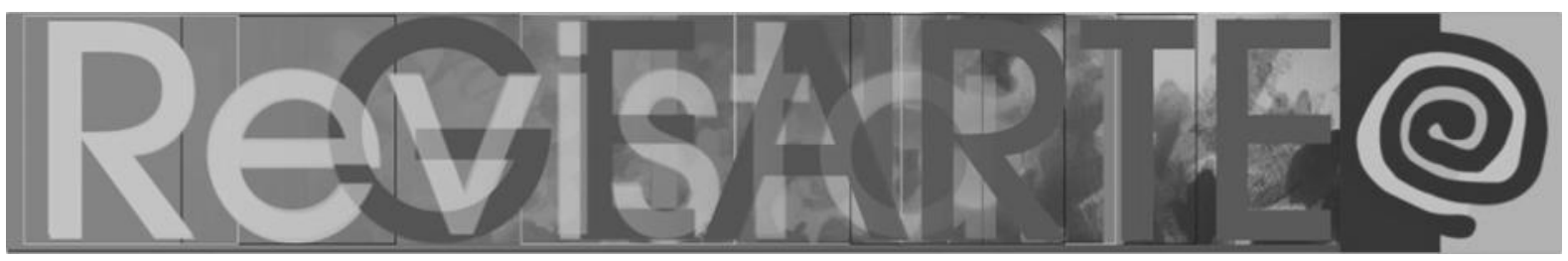

https://criancaeconsumo.org.br/biblioteca/tarja-branca-a-revolucao-que-faltava/. Acesso em: 10 abr. 2020.

UNIVERSIDADE FEDERAL FLUMINENSE. Curso de Pedagogia. Projeto pedagógico de curso. Niterói: UFF, 2018.

VECCHI, Vea. Arte e criatividade em Reggio Emilia: explorando o papel e a potencialidade do ateliê na educação da primeira infância. São Paulo: Phorte, 2017.

VECCHI, Vea. I linguaggi poetici come contrapposizione alla violenza. In: REGGIO CHILDREN. Bambini arte artisti. Reggio Emilia: Reggio Children, 2007, p. 137-143.

VECCHI, Vea. O papel do atelierista. In: EDWARDS, Carolyn; GANDINI, Lella; FORMAN, George (Orgs.). As cem linguagens da criança: a abordagem de Reggio Emilia na educação da primeira infância. Porto Alegre: Artmed, 1999, p. 129-141.

\section{Luciana Esmeralda Ostetto}

Professora da Faculdade de Educação - Universidade Federal Fluminense, atua na pós-graduação (Mestrado e Doutorado em Educação) e na graduação (curso de Pedagogia). Foi professora do Centro de Educação - Universidade Federal de Santa Catarina (1995-2012). Possui doutorado em Educação pela Universidade Estadual de Campinas (2006), mestrado em Educação pela Universidade Federal de São Carlos (1992) e graduação em Pedagogia pela Universidade Federal de Santa Catarina (1985). Articula ensino, pesquisa e extensão na área de Educação, com ênfase em Educação Infantil e Formação de professores, contemplando principalmente os seguintes temas: educação infantil e prática pedagógica, arte e infância, arte e formação de professores, narrativas autobiográficas. Coordenadora do FIAR - Círculo de estudos e pesquisa formação de professores, infância e arte (Faculdade de Educação UFF).

ORCID: https://orcid.org/0000-0002-1948-5090

E-mail: luesmeralda@hotmail.com

Currículo: http://lattes.cnpq.br/7470127128501920

Recebido em 24 de fevereiro de 2021

Aceito em 28 de abril de 2021 